\title{
Tall Wheatgrass Cultivar Szarvasi-1 (Elymus elongatus subsp. ponticus cv. Szarvasi-1) as a Potential Energy Crop for Semi-Arid Lands of Eastern Europe
}

\author{
Sándor Csete et al.* \\ University of Pécs \\ Hungary
}

\section{Introduction}

By 2020, proportion of renewable energy sources should be around 20 per cent of the total energy consumption in the European Union, according to the new treaty signed by European leaders in 2009. This vast amount of renewable energy can be sourced from hydroelectric, geothermal, wind, solar power and, of course, from biofuels. To achieve this ambitious target, new technologies must be invented to exploit energy from the abiotic source of renewables and new energy plant species should be developed and produced, serving as source for solid, liquid biofuels and for biogas production. The most intensively studied and used bioenergy crops include miscanthus, reed canary grass, willows and poplars. We already have considerable knowledge about these energy plants from their taxonomical relations to their detailed crop technologies. In this chapter, we introduce a novel energy plant that has been cultivated for more than a century in many parts of the world for numerous purposes (e.g. land remediation, erosion control, forage), but its potential for energy production has not yet been realized. Tall wheatgrass, a new energy crop (Elymus elongatus subsp. ponticus cv. Szarvasi-1) has recently been introduced to cultivation in Hungary to provide biomass for solid biofuel energy production. The cultivar was developed in Hungary. The main goal of our research was to investigate the performance of Szarvasi-1 energy grass under different growing conditions (e.g. soil types, nutrition supply). We focused on the ecological background, biomass yield, weed composition, morphology, ecophysiology and the genetics of the plant.

\footnotetext{
"Szilvia Stranczinger1', Bálint Szalontai ${ }^{1}$, Ágnes Farkas¹, Róbert W. Pál1, Éva Salamon-Albert1, Marianna Kocsis' ${ }^{1}$, Péter Tóvári ${ }^{3}$, Tibor Vojtela ${ }^{3}$, József Dezső' ${ }^{1}$, Ilona Walcz ${ }^{1}$,

Zsolt Janowszky², János Janowszky² and Attila Borhidi ${ }^{1}$

1 University of Pécs, Hungary

${ }^{2}$ Hungaro-Grass Kft, Hungary

${ }^{3}$ Hungarian Institute of Agricultural Engineering, Hungary
} 


\section{Description}

\subsection{Origin and distribution}

Tall wheatgrass is a Pontic-Mediterranean grass species. Its distribution ranges along the Mediterranean Basin from the Black Sea to the Iberian Peninsula. This vast area is covered by two, morphologically very different subspecies. The shorter and more fragile E. elongatus (Host) Runemark subsp. elongatus occurs in the western basin of the Pontus-Mediterranean area, while the taller and more robust E. elongatus (Host) Runemark subsp. ponticus (Podp.) Melderis occupies the Eastern Mediterranean Basin. The latter is also native to Hungary, reaching the north-westernmost part of its distribution in this area (Tutin et al., 1980).

Szarvasi-1 energy grass was bred as an intra-specific hybrid of drought-tolerant and robust E. elongatus subsp. ponticus populations from Hungary and from different pontic areas (Janowsky \& Janowszky, 2007). The 10-year-long breeding process was conducted in Szarvas (East Hungary) but more recently the new breed has been involved in extensive crop management studies in different parts of the country. The Szarvasi- 1 tall wheatgrass cultivar was officially recognized by the Hungarian Central Agricultural Office in 2004.

\subsection{Taxonomy and nomenclature of Elymus elongatus}

Classification and nomenclature of wheatgrass species has been the subject of much taxonomic debate (Assadi \& Runemark, 1995; Mizianty et al., 1999; Murphy \& Jones, 1999). Consequently, representatives of this genus are known by several scientific and vernacular names. Synonyms of Elymus elongatus (Host) Runemark (tall wheatgrass) include: Agropyron elongatum (Host) Beauv., Elytrigia elongata (Host) Nevski, E. pontica (Podp.) Holub, Elymus varnensis (Velen.) Runemark, Lophopyrum elongatum (Host) A. Löve and Thinopyrum ponticum (Podp.) Liu \& Wang.

\subsection{Genetic diversity of energy grass cultivar Szarvasi-1}

Besides studying the agronomical features of Szarvasi-1, it was important to reveal its genetic background, in order to ascertain its taxonomic position in the system of grasses (focusing on the Triticeae tribe), to assess genetic similarities among the closely related Agropyron and Elymus genera and to establish genetic relationships among native Hungarian populations of E. elongatus (the hypothesised ancestor of Szarvasi-1) and the cultivar.

As a first step the genetic background of Szarvasi-1 and its relatives was studied by RAPD (Randomly Amplified Polymorphic DNA) technique, which allowed the random study of the whole genome with no prior knowledge required. RAPDs can produce a large set of markers, which can be used for the evaluation of both between- and within-species genetic variation, more rapidly and easily than isozymes and microsatellites (Guadagnuolo et al., 2001). To determine the exact taxonomic position of the cultivar among its relatives, specific primers for sequencing specific DNA regions were used. The sequences were compared and phylogenetically analysed. Our results indicated a potential risk of gene flow, which is a possible disadvantage of planting Szarvasi-1 energy grass on large scale.

\subsubsection{Interspecific study}

The interspecific variation of three Elymus and an Agropyron species together with the Szarvasi-1 cultivar was screened with 61 RAPD primers (Table 1.). The most informative 16 
primers were retained, due to their ability to produce polymorphic, unambiguous and stable RAPD markers. Various banding patterns were revealed by different primers, but only polymorphic fragments of high intensity and moderate size (between 100 and $3000 \mathrm{bp}$ ) were used. About $98 \%$ (131 bands) of the total number of bands (136) were polymorphic. Though the high number of polymorphic bands allows the easy differentiation of analyzed samples using RAPD markers, it gives poor information regarding the relationships among the studied taxa.

\begin{tabular}{|c|c|c|}
\hline Genus & Species & Synonyms \\
\hline Agropyron Gaertner & cristatum (L.) Gaertner & Eremopyrum cristatum (L.) Willk. \\
\hline \multirow{3}{*}{$\begin{array}{l}\text { Elymus L. } \\
\text { (Roegneria Koch, } \\
\text { Elytrigia Desv., } \\
\text { Clinelymus (Griseb.) } \\
\text { Nevski) }\end{array}$} & elongatus (Host)Runemark & $\begin{array}{l}\text { Triticum elongatum Host } \\
\text { Agropyron elongatum (Host) Beauv. }\end{array}$ \\
\hline & repens (L.) Gould & $\begin{array}{l}\text { Triticum repens L. } \\
\text { Agropyron repens (L.) Beauv } \\
\text { Elytrigia repens (L.) Nevski }\end{array}$ \\
\hline & hispidus (Opiz) Melderis & $\begin{array}{l}\text { Agropyron hispidum Opiz } \\
\text { Agropyron intermedium (Host) Beauv. }\end{array}$ \\
\hline
\end{tabular}

Table 1. Hungarian Agropyron and Elymus taxa used in the interspecies study

Sequence analysis was performed for two DNA regions: the rpoA gene of the plastid genome including partial sequences of petD and rps11 genes, which was successfully applied by Gitta Petersen and Ole Seberg (1997) to study the Triticeae tribe; and the intergenic spacers (ITS) of the rDNA, an extensively used marker in molecular phylogeny. These analyses resolved the exact taxonomic position of Szarvasi-1. Plant materials were collected from field and identified carefully using morphological characters. Total DNA was extracted from leaves, the targeted DNA loci were amplified in polymerase chain reactions (PCR) and sequenced. New DNA sequence data were deposited to GenBank. Cladistic analyses were performed with PAUP* 4.0 software (Swofford, 2001) on Windows $\mathrm{XP}$, using maximum parsimony, supplemented with additional public sequence data referring to the tribe. Bromus inermis was used as an outgroup. The analysis comprised 32 sequences representing 21 of the 24 monogenomic genera of the Triticeae. In the case of the rpoA data, the final matrix contained 1385 characters, of which $1276(92 \%)$ were constant, $84(6 \%)$ variable but uninformative and $25(1.8 \%)$ informative. The analysis resulted in a 129-step-long parsimonious tree (Fig. 1.A) (consistency index including all characters $=0.9225$, consistency index excluding uninformative characters $=0.7368$, retention index $=0.9048$ ). However, the results were based on only a small number of phylogenetically informative characters $(1.8 \%)$ - concentrated mostly in the non-coding spacer regions. Therefore the study was completed by the analysis based on the nuclear ribosomal internal transcribed spacers (ITS) (Fig. 1.B). In the latter case the final matrix included 596 characters: 459 (77\%) were constant, $53(8.9 \%)$ variable but uninformative and $83(13.4 \%)$ informative (tree length $=214$ steps long, consistency index including all characters $=0.7617$, consistency index excluding uninformative characters $=0.6731$, retention index $=0.7475)$. In both cases, four sequences - E. elongatus, E. elongatus subsp. ponticus cv. Szarvasi-1, E. hispidus, and A. cristatum - were newly determined.

The phylogenetic relationships inferred from molecular data of both the rpoA gene and ITS regions supported the separation of the studied Elymus taxa from A. cristatum - formerly 
also declared an Elymus species. All of the studied Elymus taxa form a well supported clade within Pseudoroegneria, Lophopyrum, and Festucopsis, corresponding with the results of Sha et al. (2010). Interestingly, the Hungarian A. cristatum is located far from the Danish accession of the species on the rpoA based phylogenetic tree. However, the rpoA sequence of E.hispidus and the ITS sequence of E. repens are very similar to those of the Szarvasi-1, suggesting the possibility of unwanted hybridization.

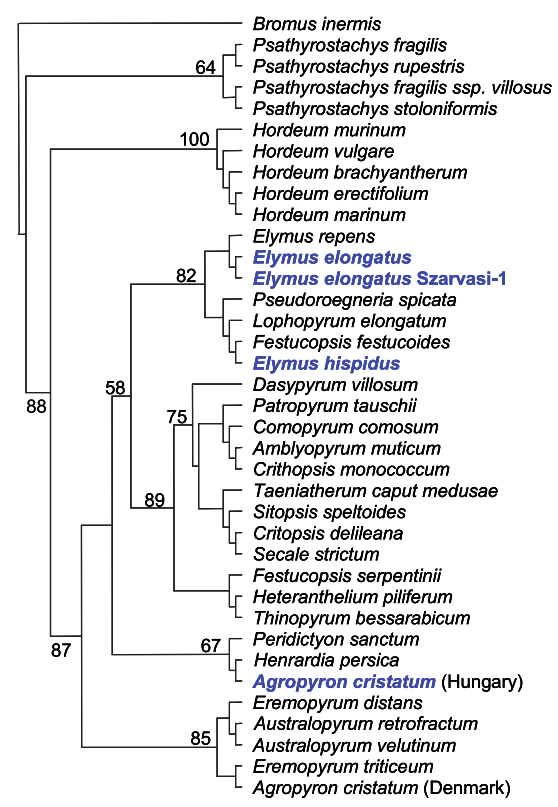

A.

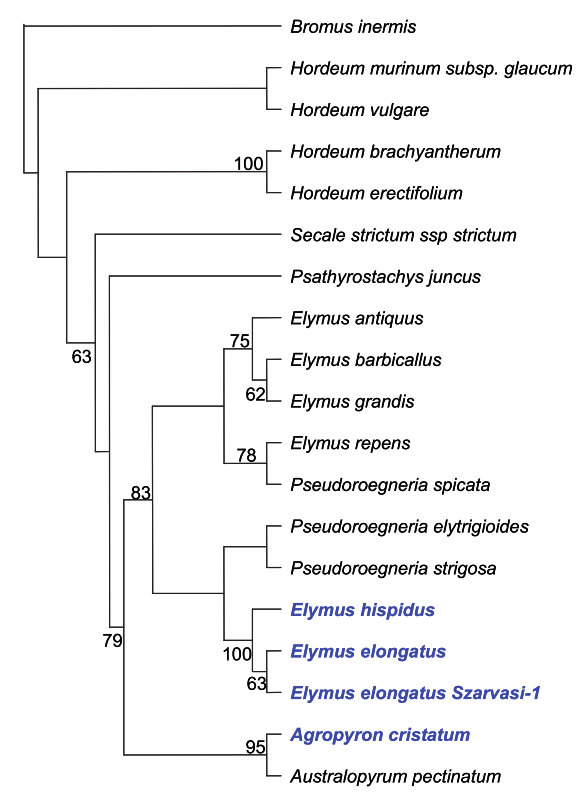

B.

Fig. 1. Strict consensus tree based on phylogenetic analysis A: of the rpoA gene B: of the ITS sequence data. Numbers above and below branches indicate bootstrap support.

\subsubsection{Interpopulational studies}

The interpopulation study compared 15 individuals from each population of E. elongatus and the Szarvasi-1 cultivar by RAPD markers. The samples originated from four different locations in Hungary: Hortobágy, Kunadacs, Tiszaalpár and Szarvasi-1 from Görcsöny. The method can be a valuable tool for populational studies (Reisch et al., 2003), though it has often been criticized for low reproducibility; in order to avoid this phenomenon, highly constant conditions were used and all reactions were repeated at least twice. The samples were screened with a total of 80 arbitrary 10-mer primers, out of which only 30 informative primers were retained. The total number of analyzed bands was 373 . The percentage of polymorphic bands was $41.3 \%$ (154 bands). The RAPD data were used for calculation of pairwise genetic distances using the Simple matching coefficient. The distance matrix was used for cluster analysis using UPGMA (unweighted pair-group method with arithmetic averages). A dendrogram was generated using SYN-TAX 5.0 (Podani, 1993).

Consistent with other results (Díaz et al., 2000; Nieto-Lopez et al., 2000), RAPD analysis discriminated the studied populations. The samples from Kunadacs constituted the most 
homogenous population, the samples differed from each other by only $0.8 \%$. The most heterogeneous population seemed to be the population of Hortobágy with $3.8 \%$ difference among individuals. According to the present state of our knowledge of the genetic relationships of Szarvasi-1 and other studied Hungarian tall wheatgrass populations we can claim that there is no genetic difference between the genotype of the Szarvasi- 1 cultivar and that of the population of Hortobágy. This result suggests that the genetic material of the populations from pontic areas involved in the breeding process could disappear during the process. The ability to differentiate the tested populations by RAPD bands suggested that this technique may provide a rapid and inexpensive method for the identification of the three Elymus populations in Hungary and can be used to monitor the possible changes of energy grass genotype by outcrossing different, closely related Elymus taxa during their utilization.

\subsection{Morphology and anatomy of Elymus elongatus subsp. ponticus and Szarvasi-1 energy grass}

Elymus species are caespitose or rhizomatous perennials. The roots of E. elongatus are fibrous (Fig. 2.), and can reach lengths of $3.5 \mathrm{~m}$. E. elongatus can grow to a height of $50-200 \mathrm{~cm}$ (Melderis, 1980; Barkworth, 2011), while Szarvasi-1 energy grass can reach 180-220 cm under optimal growing conditions. From the wheatgrass species that are native to Hungary, three members of the genus Elymus and a closely related Agropyron species were picked for morphological comparison with Szarvasi-1 energy grass (Fig. 3.), taking into consideration both their vegetative (Table 2.) and reproductive features (Table 3.).

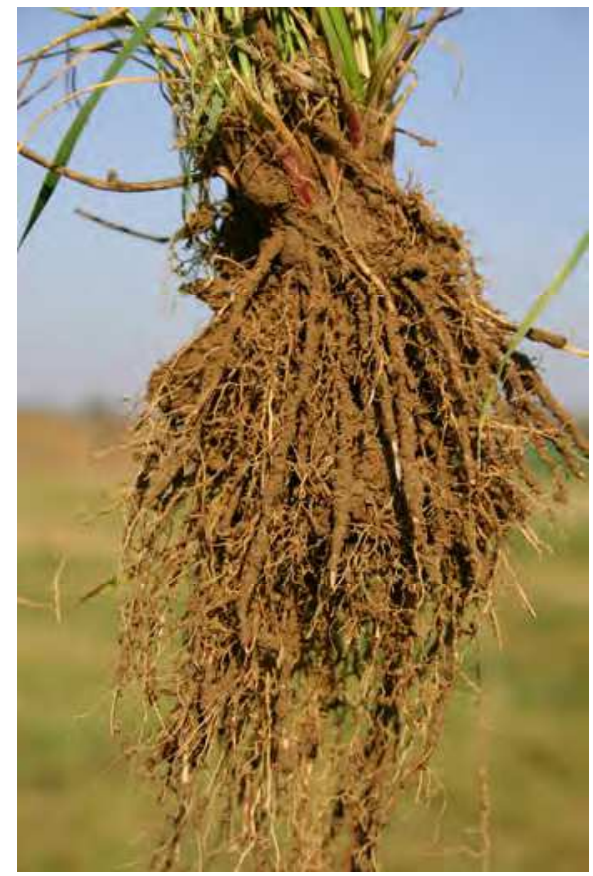

Fig. 2. Fibrous root system of Szarvasi-1 energy grass (photo: Róbert W. Pál) 


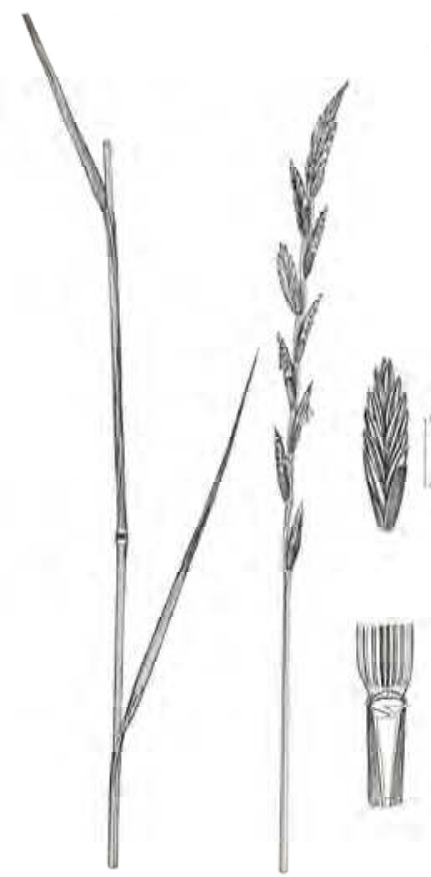

Fig. 3. Stem, leaf, inflorescence and spikelet of Szarvasi-1 energy grass (drawing: Emőke Oláh)

\begin{tabular}{|c|c|c|c|c|c|}
\hline \multirow{2}{*}{$\begin{array}{l}\text { Taxon / } \\
\text { Character }\end{array}$} & \multirow[b]{2}{*}{ Root system } & \multirow{2}{*}{$\begin{array}{c}\text { Stem } \\
\text { height } \\
(\mathrm{cm})\end{array}$} & \multicolumn{3}{|c|}{ Leaf } \\
\hline & & & leaf blade & ligule & auricle \\
\hline A. pectiniforme & fibrous & $25-60$ & $\begin{array}{l}\text { adaxial side with } \\
\text { trichomes }\end{array}$ & $\begin{array}{c}\text { membranous, } \\
\text { truncate }\end{array}$ & - \\
\hline E. repens & rhizomatous & $40-120$ & dense venation & $\begin{array}{c}\text { membranous, } \\
\text { truncate }\end{array}$ & long \\
\hline E. hispidus & rhizomatous & $40-150$ & $\begin{array}{c}\text { long, sparse } \\
\text { trichomes on } \\
\text { adaxial side }\end{array}$ & $\begin{array}{l}\text { membranous, } \\
\text { truncate }\end{array}$ & medium \\
\hline E. elongatus & fibrous & $50-200$ & $\begin{array}{c}\text { prominent } \\
\text { venation, surface } \\
\text { and margin bearing } \\
\text { spinules }\end{array}$ & $\begin{array}{c}\text { membranous, } \\
\text { dentate }\end{array}$ & medium \\
\hline Szarvasi-1 & fibrous & $50-220$ & $\begin{array}{c}\text { prominent } \\
\text { venation, surface } \\
\text { and margin bearing } \\
\text { spinules }\end{array}$ & $\begin{array}{c}\text { membranous, } \\
\text { dentate }\end{array}$ & long \\
\hline
\end{tabular}

Table 2. Vegetative features of wheatgrass (Elymus and Agropyron) taxa (data are based on our own observations and some literature references, see Melderis, 1980 and Barkworth, 2011) 
The stems of E. elongatus are robust and glabrous (Melderis, 1980). Our comparative histological studies, conducted on E. hispidus, E. elongatus and Szarvasi-1 energy grass, revealed that in Szarvasi-1 the epidermis of the stem is sclerenchymatous (Fig. 4.), covered with a thick cuticle, which suggests drought tolerance of the cultivar. Stomatal guard cells are in level with the epidermal cells (mesomorphic position), both in the stem (Fig. 4.) and the surrounding leaf sheath, which is typical in plants that require a moderate water supply. In the internodes collateral closed vascular bundles are arranged in two rings, embedded in the sclerenchymatous hypodermis and parenchyma. In the outermost cortical region of the culm in Szarvasi-1, clorenchyma alternates with sclerenchyma, or a continuous sclerenchymatous ring is formed. Third order vascular bundles are located in the hypodermis, while first and second order bundles can be found toward the centre of the stem (Fig. 5.). Vascular bundles are supported by a sclerenchymatous sheath and/or bundle cap, the latter often establishing direct contact with the hypodermal sclerenchymatous fascicles in the case of the outer vascular bundles.

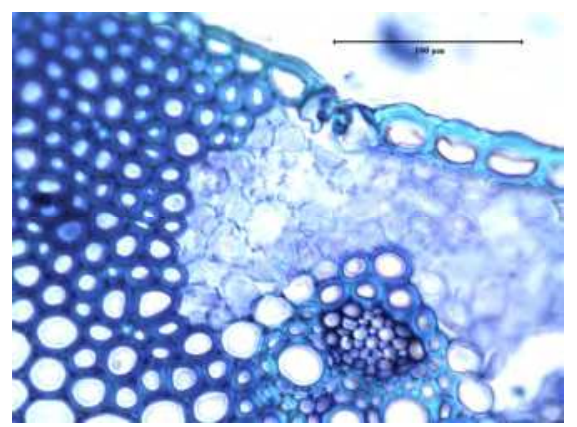

Fig. 4. Sclerenchymatous epidermis with mesomorphic stoma in the stem of Szarvasi-1 (photo: Ágnes Farkas)

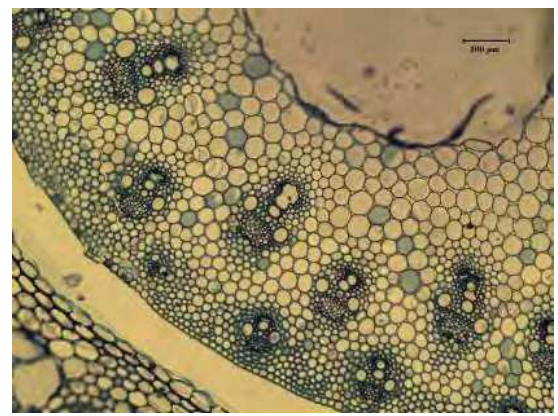

Fig. 5. Vascular bundles of varying size in the stem of Szarvasi-1 energy grass (photo: Ágnes Farkas)

In the nodes of Elymus species, the bundles located in the outer region possess a welldeveloped sclerenchymatous bundle cap, which is kernel-shaped in E. elongatus (Fig. 6.) and ovate in E. hispidus. The phloem consists of sieve tubes and companion cells; the xylem comprises two large tracheas, tracheids and xylem parenchyma, accompanied by a 
rexigenous intercellular space. The walls of vessels and tracheids are strengthened by annular or spiral thickening (Fig. 7.).

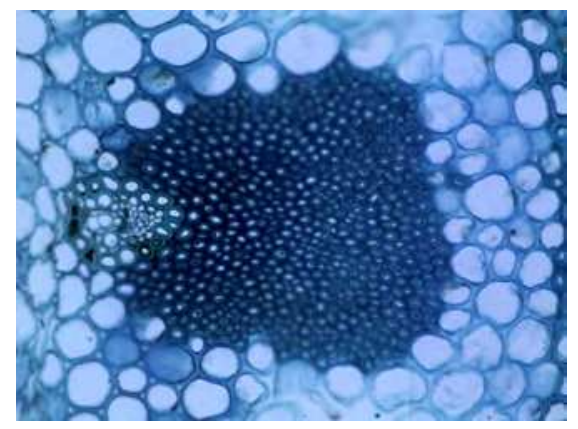

Fig. 6. Bundle cap in the stem of Szarvasi-1 (photo: Ágnes Farkas)

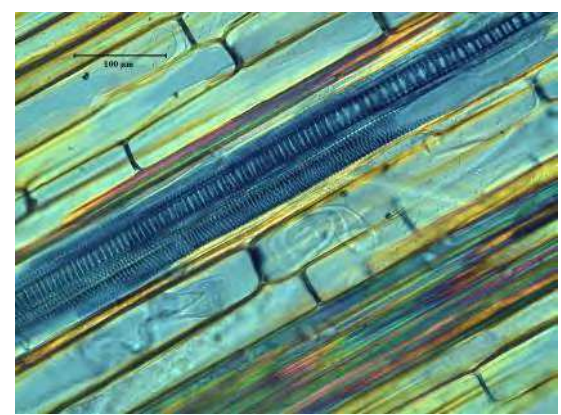

Fig. 7. Vessels with annular and spiral thickening in the stem of Szarvasi-1 (photo: Ágnes Farkas)

The leaves of Elymus species are flat or more or less convolute (Melderis, 1980). In E. elongatus they are convolute, however, in Szarvasi- 1 this feature is not typical. The leaf blade is grey-green in E. elongatus, as opposed to the blue-grey colour of E. hispidus (Melderis, 1980). The leaf blade of E. elongatus is $2.5-5 \mathrm{~mm}$ wide, prominently and closely veined. Similarly to E. hispidus, one margin of the leaf sheath can bear trichomes in E. elongatus as well; sparse spinules, and sometimes also short setae can be observed on the surface and the edge of the leaf (Melderis, 1980). The ligule is short and membranous; the presence and length of the auricle varies with Elymus species (Table 2.) (Häfliger \& Scholz, 1980; Melderis, 1980; Barkworth, 2011).

The leaf epidermis in Szarvasi-1 is mostly sclerenchymatized, with thickened cell walls and a thick layer of cuticle, all of which highlight drought tolerance of the energy grass. In the intercostal region of the adaxial epidermis, a group of large bulliform cells can frequently be observed, which play a role in rolling up the leaf blade in the case of drought, thereby reducing transpiration. Both the adaxial and abaxial epidermis may contain stomata, however, they are more frequent on the abaxial side. Most stomatal guard cells are at the level of epidermal cells (mesomorphic position), however, in some cases guard cells may rise above the epidermis (hygromorphic position), or the stoma can become slightly sunken 
(xeromorphic position), when guard cells reach the bottom half of epidermal cells. Nonglandular trichomes (bristles) are present in large numbers (Fig. 8.), especially on the adaxial side of the leaf, enhancing the drought-tolerance of the plant by reducing water loss. The two epidermal layers sandwich a chlorenchymatous, homogenous mesophyll layer, consisting of spongy parenchyma. In Szarvasi-1 energy grass the basal leaf blade is strongly wavy in transverse section, due to the ridges formed by the longitudinally running veins that correspond to collateral closed bundles, arranged in a characteristic pattern formed by the alternation of smaller and larger bundles (Fig. 9.). The vascular bundles are surrounded by an inner sclerenchymatous and an outer parenchymatous bundle sheath. Bundles of first order are accompanied by hypodermal sclerenchyma. In both E. elongatus and Szarvasi-1 the sclerenchymatous bundle cap is more developed than in E. hispidus. In E. elongatus cell wall thickening also reaches a higher level in the sclerenchymatous tissues. In the adaxial part of the primary bundles we can often see rexigenous intercellular spaces, containing the broken elements of the protoxylem.

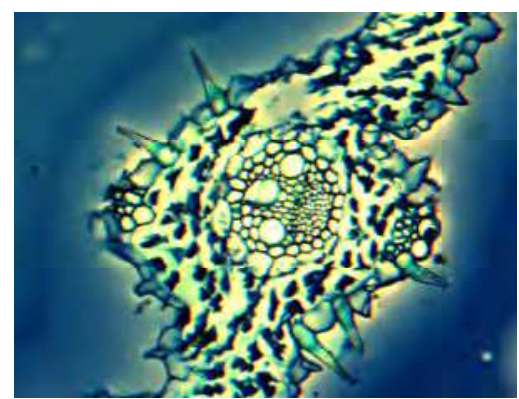

Fig. 8. Non-glandular trichomes on the leaf of Szarvasi-1 (photo: Ágnes Farkas)

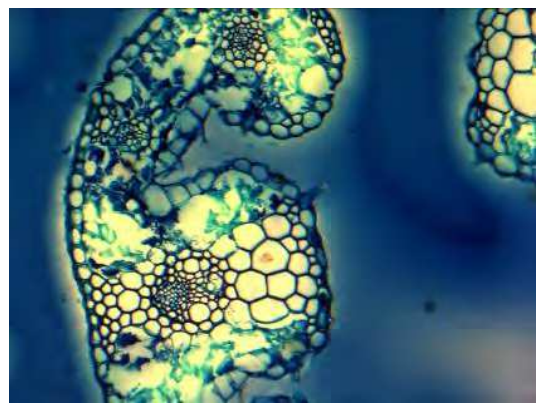

Fig. 9. Vascular bundles in the leaf of Szarvasi-1 (photo: Ágnes Farkas)

The inflorescence is an erect spike, which is long and slender in each wheatgrass species, except for A. pectiniforme, where it is short and dense, with numerous, overlapping spikelets. In E. elongatus the rachis is nearly flat on the side facing the spikelets, usually spinose-ciliate on the main angles (Melderis, 1980). Compared to E. repens, the spikelets are less overlapping and more loosely arranged in E. elongatus, sitting close to the rachis, and strongly compressed laterally; the rachilla is strigulose. The spikelet consists of varying numbers of florets in each species (Table 3.). 


\begin{tabular}{|c|c|c|c|c|}
\hline $\begin{array}{c}\text { Taxon / } \\
\text { Character }\end{array}$ & $\begin{array}{c}\text { Number of } \\
\text { florets/spikelet }\end{array}$ & Glume & Lemma & Palea \\
\hline A. pectiniforme & $4-8$ & $\begin{array}{l}\text { abruptly } \\
\text { narrowing }\end{array}$ & short-awned & $\begin{array}{c}\text { keel with short } \\
\text { trichomes }\end{array}$ \\
\hline E. repens & $4-8$ & acute, tapering & acute & \\
\hline E. hispidus & $4-8$ & truncate & obtuse or acute & $\begin{array}{c}\text { keel with short } \\
\text { trichomes }\end{array}$ \\
\hline E. elongatus & $5-11$ & truncate, glabrous & obtuse, awnless & two-keeled \\
\hline Szarvasi-1 & $7-15$ & truncate & obtuse, awnless & two-keeled \\
\hline
\end{tabular}

Table 3. Reproductive features of wheatgrass (Elymus and Agropyron) taxa

The glumes of Elymus species are indurate-coriaceous, obtuse or truncate, with 1-11 veins, possessing a short awn or no awn at all. The glume can reach half or two thirds of the spikelet in A. pectiniforme, two thirds of the spikelet in E. repens, and one third of the spikelet in E. hispidus, E. elongatus and Szarvasi-1 (Fig. 3.). The glumes are 1-3-veined in A. pectiniforme, and 3-7-veined in the other taxa. The lemma of E. elongatus is obtuse, glabrous, unawned and 5-veined; the palea is two-keeled (Melderis, 1980; Barkworth, 2011). Similarly to other representatives of the Poaceae family, the stigma is feather-like in the Elymus genus, where stigmatic secretion is absent even in the mature stage of the stigma, and the receptive surface is discontinuous (Heslop-Harrison \& Shivanna, 1977). The fruit is a caryopsis.

The evaluated anatomical features allow the differentiation of E. elongatus and Szarvasi-1 energy grass from the other investigated members of the Agropyron-Elymus complex. Szarvasi-1 shows several anatomical traits that enhance drought tolerance, such as a sclerenchymatized epidermis covered by a thick cuticle and dense coverage by nonglandular hairs. On the other hand, the mesomorphic position of stoma guard cells is characteristic of an intermediate water requirement. This dual nature of the habitat tolerance of Elymus elongatus cv. Szarvasi-1 has to be taken into account when the new cropfields of this energy grass are planned.

\section{Ecological requirements}

\subsection{Habitat preferences}

Szarvasi-1 energy grass prefers soil conditions similar to common cereals in terms of soil texture, nutrient and water content. However, on lighter soils (e.g. sandy, sandy-silt) it develops faster compared to medium or heavy soils. On sand and sandy soils it can develop seeds in the first year (after spring sowing) and reaches its maximal photosynthetic assimilation one phenophase earlier. The natural habitats of this indigenous plant mainly occur in the central part of Hungary, where the largest sandy areas are located, but it also has an exceptionally natural population on a more clay type soil in a salty marsh.

Considering only the habitats of the natural populations, tall wheatgrass seems to prefer rather alkaline soils where the $\mathrm{pH}$ is between 6.5 and 10 . However, optimal growing potential and biomass production can be linked to a narrower $\mathrm{pH}$ range of 7.5-9. This means that energy grass, in spite of its alkaline origin, can show a more pronounced biomass production in a near neutral soil $\mathrm{pH}$, similarly to the most common cereal cultivations. Slightly acidic soils do not hinder good biomass production, but soil $\mathrm{pH}$ below 5.5 negatively affects the yield. 
The life span of Szarvasi-1 energy grass cultivation can be 10-15 years long, but the temporal change of biomass production during this time has not yet been monitored sufficiently. We have only one complete data series monitoring the yields of an energy grass field on solonec alkaline soil for more than 10 years. According to this study it takes two years for energy grass cultivation to reach maximal biomass production, which can then be maintained for at least 7 years. At around the tenth year energy grass cultivation starts decrease in yearly biomass production. In semi-arid climates without a ground water table serving as water source for cultivation the durability of the energy grass crops can be much shorter.

The flood tolerance of energy grass is relatively good, especially when the cultivation is at least two or three years old and the tussocks of the individuals are well developed. However, in the first year, the short and weak stems of the juveniles cannot tolerate permanent water cover and die out. Hence, the cultivated energy grass stand opens, the density of the stems declines and the establishment of the grass cultivation remains incomplete. In such a condition, weeds can gain multiple chances to invade and to establish. High salt concentrations of the soil can be tolerated by Szarvasi-1 energy grass, but only in wet habitats, where a several weeks long seasonal high water table can occur every year. Because of the high salt resistance, Szarvasi-1 energy grass can be used as salt-tolerant forage and can play an important role in the recycling of saline drainage waters for irrigation.

Since Elymus elongatus subsp. ponticus is a native species of the continental and subcontinental climate in Eastern Europe, it tolerates well the summer high temperatures exceeding daily means of even $30-35^{\circ} \mathrm{C}$, and can also resist cold winter days when the temperature sinks below $-35^{\circ} \mathrm{C}$.

\subsection{Gas exchange behaviour}

Tall wheatgrass is classified as $C_{3}$ plant with cool season characteristics and seasonally different water use efficiency in moderately saline habitats (Bleby et al., 1997; Johnson, 1991). Several cultivars have previously been developed based on adaptability to different environmental conditions in Europe and Asia, but not from ecophysiological perspective. Szarvasi-1 energy grass was developed from a native population of tall wheatgrass (Elymus elongatus subsp. ponticus) that was adapted to slightly salty habitats. Therefore it was expected that E. elongatus cv. Szarvasi-1 will be a good candidate for biomass crop status because it produces large amounts of organic matter with relatively broad tolerance spectra and a high adaptability to different environments. Here we review the current knowledge on environmental gas exchange responses of Szarvasi-1 energy grass under greenhouse and field conditions to different environmental parameters such as temperature, light, air humidity and carbon-dioxide.

We used the following photosynthetic parameters: assimilation as the measure of carbondioxide fixation, transpiration as the measure of water loss and photosynthetic water use efficiency as the ratio of carbon-dioxide input to water output. All of these parameters depend on stomatal regulation and the abiotic environment. In this section capacities and threshold limits of Szarvasi-1 energy grass gas exchange performance will be presented for a better knowledge of its abiotic environmental requirements (Fig. 10.). To define and to compare gas exchange capacities, growing pots were installed using three soil types (sandy soil, Alfisol-Mollisol, Aquic Mollisol) in the Botanic Garden of the University of Pécs with permanent irrigation. In addition, field experiments were established on three soil types (Alfisol, Alfisol-Mollisol, Aquic Mollisol) in South 
Hungary, under natural climatic conditions without any irrigation or fertilization. To evaluate threshold values of gas exchange parameters under different environmental regime, steady state and instantaneous field measurements by IRGA methods were executed.

Among investigated abiotic environmental parameters photon flux density and air humidity turned out to have an essential role in gas exchange performance and regulation (SalamonAlbert \& Molnár, 2009, 2010). Under non-stressed soil water conditions (P2, P3, P5) carbon fixation was the most favourable at the beginning of the growing period described by the assimilation capacity and light efficiency regulated by the air humidity (Fig. 10.A). After seasonal precipitation deficiency in late summer (P4), causing a decline in soil water content, hard reduction was detected in water use efficiency because of strong decrease in assimilation capacity and light efficiency, retaining a regular level of transpiration (Fig. 10.B,C). Effect of climatic air drought was significant for stomatal conductance, going shattered in seasonal response by a greater effectiveness to transpiration (Fig. 10.D). As for the other experimental soil types, overall and seasonal assimilation capacity and light efficiency was a little bit lower on Alfisol-Mollisol and significantly depressed on Aquic Mollisol.
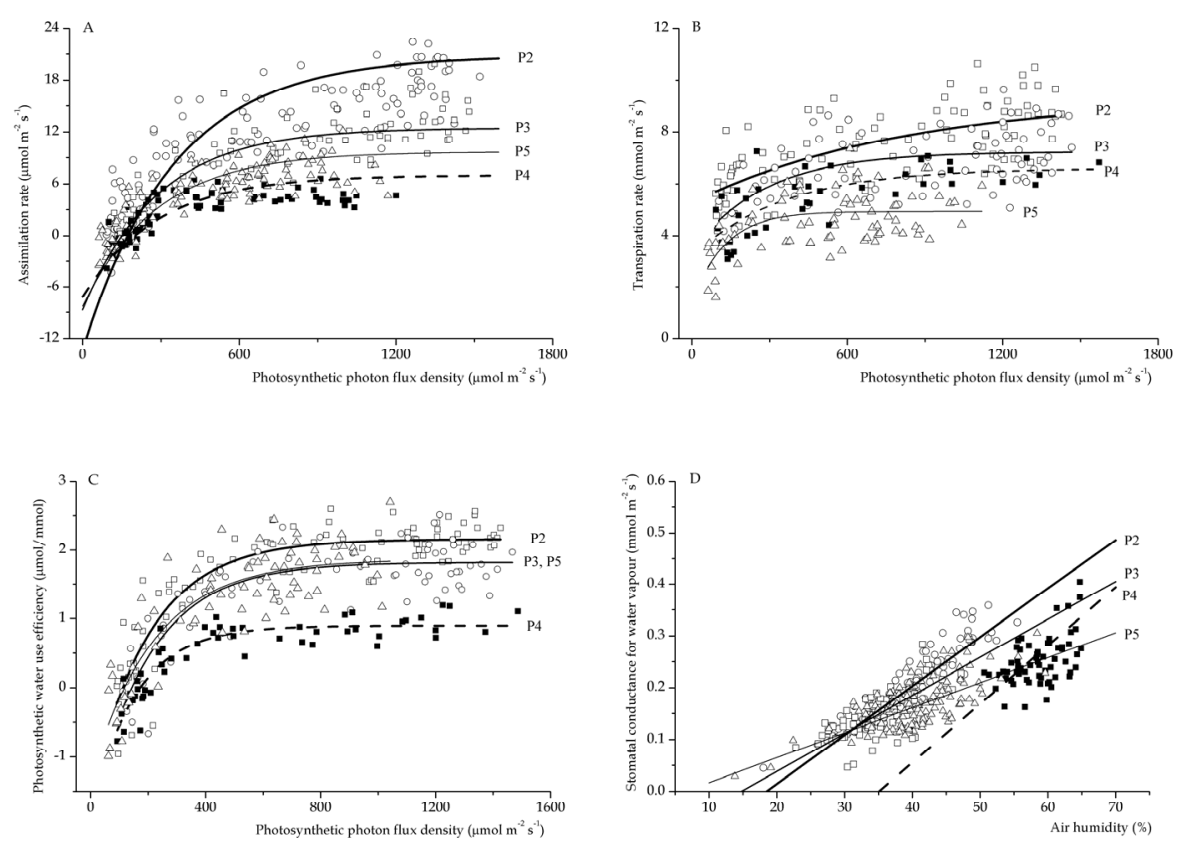

Fig. 10. A) assimilation, B) transpiration, C) photosynthetic water use efficiency as a function of light and D) stomatal conductance for water vapour as a function of air humidity, derived from field measurement (instantaneous data, alfisol, unpublished). Fitted curves $p<0.01$, P2P5 the vegetative phenophases. 
The assimilation and its capacity as the highest net photosynthetic rate in cultivated and natural $C_{3}$ grasses vary greatly from slight to medium values $\left(20-40 \mu \mathrm{mol} \mathrm{m}^{-2} \mathrm{sec}^{-1}\right)$ and in the case of $\mathrm{C}_{4}$ crops from medium to high $\left(30-70 \mu \mathrm{mol} \mathrm{m} \mathrm{m}^{-2} \mathrm{sec}^{-1}\right)$ values under natural carbon-dioxide conditions, saturated light intensity, optimal temperature and adequate water supply (Larcher, 2003). Comparing Szarvasi-1 energy grass to other grasses or crop species, it has a low-medium assimilation capacity among $C_{3}$ species with a range of 10.3 $19.2 \mu \mathrm{mol} \mathrm{m} \mathrm{mec}^{-1}$ in greenhouse, and $10.6-20.3 \mu \mathrm{mol} \mathrm{m}^{-2} \mathrm{sec}^{-1}$ under field conditions. Optimal water use efficiency was measured under moderate light intensity (500-1100 $\mu \mathrm{mol}$ $\mathrm{m}^{-2} \mathrm{sec}^{-1}$ ) on all of the studied soil types under greenhouse conditions, while the maximum value was observed on sandy soil in spring $(3.73 \mu \mathrm{mol} / \mathrm{mmol})$. Time and phase shifting in plant growth, poor seasonal rates of assimilation and low water use efficiency detected on Aquic Mollisol under both irrigated and climatic drought conditions underline the negative effect of high clay content of soils on the optimal biomass production of energy grass crops. This is presumably due to insufficient water and nutrient availability.

Under non-stressed environmental conditions, optimum gas exchange in Szarvasi-1 energy grass occurred at the beginning of development in early or late spring, depending on irrigation and soil type. Climatic drought has a strong effect on gas exchange performance through the regulation of stomatal conductance, both for carbon-dioxide and water vapour. According to the studied ecophysiological parameters, Szarvasi-1 energy grass could be beneficial as an energy crop in mesic habitats with lighter soils.

\section{Propagation}

Szarvasi-1 energy grass is propagated by seed. Since E. elongatus ssp. ponticus has evolved in regions of Europe that have long and severe winters, it germinates relatively late in the spring and by the time it develops its tussocks it is mid summer. This is why the suggested sowing time is in autumn, in the middle of September. Its germination needs no special circumstances. A period of only 7 consecutive days with approx. 16 hours dark each day and $18-20{ }^{\circ} \mathrm{C}$ air temperatures can maximize the germination success, up to $90 \%$. In different conditions the proportion of germinating seeds can vary between 52 and $90 \%$. Seedlings die rapidly without proper humidity conditions, but too much watering or a high water table are also poorly tolerated by Szarvasi-1 energy grass seedlings and juveniles. Similarly, strong competition of weeds can dramatically reduce seedling survival. The plant gets in full flower by the middle of June. The energy grass seeds belong to the transient seed bank-type, where the longevity of the seeds is shorter than a year. Hence, the seed bank of Szarvasi-1 energy grass fields contains seeds with the same age with no overlapping generations.

\section{Crop management and production}

The recommended sowing time is between the $1^{\text {st }}$ and $20^{\text {th }}$ of September. The soil must be prepared similarly to any other cereals (e.g. wheat, barley etc). The seeds should be sown at the depth of 2-2.5 cm with the sowing distance of $12-15 \mathrm{~cm}$. The seed quantity for a hectare land is approx. $40 \mathrm{~kg}$. The seedlings emerge in 14-18 days. Weed management is necessary in this phase of the development of energy grass plantations to avoid the weed species strengthening at the expense of energy grass individuals. In the early spring rolling on the plantation can be important to mitigate the negative effects of winter frost on the root 
system. The first cut can be made in the Central European climate at the beginning of July when the plantation is in full flower. The later the cut takes place the lower the water content is in the biomass as it is shown in Fig. 11. The water content of the biomass is highest in fresh plant material in spring (approx. $80 \%$ ), but during the process of ripening it decreases to $50 \%$ resulting in a higher dry material ratio. Although the highest biomass weight for a unit area can be measured in late spring, the highest dry material weight can be achieved just in the late summer when the seeds are already ripe. The fresh biomass weight reaches its peak with the appearance of the inflorescence, however the high water content decreases its value as solid biofuel. In early August when seeds are ripening plant biomass has a moderately smaller fresh weight but with the highest dry material content. Thereafter, during the autumn (this is not depicted in the figure), dry biomass weight decreases more intensively than water content indicating some loss in dry material content, too.

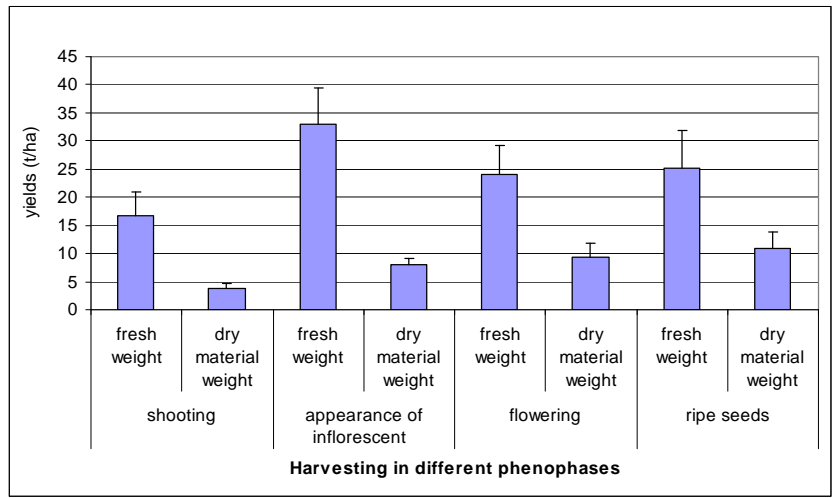

Fig. 11. Changes in fresh and dry weight of yields during a growing season on solonec meadow soil type (mean and SD)

Three or 5 days of full sunshine can reduce the water content of Szarvasi- 1 energy grass hay to $9-12 \%$ when it is ready to be baled. In this dry condition the bales can be stored for a long time without a chance of rotting. Later, during the autumn a second mow can be made in October resulting in a lower quantity of biomass with higher content of protein content. The second harvest can be used as forage for cattle or can be grazed in situ.

Soil type has a considerable effect on biomass yields. In the same macroclimatic condition the average weight of the harvested biomass for a unit land can be as much as two times higher thanks to different water and nutrient availability as well as physical soil properties such as texture and compactness of the used soil. An example of this is shown in Fig. 12.

Three soil types were chosen to represent the effect of soil on the yields of energy grass plantations. Alfisol, Alfisol-Mollisol and Aquic Mollisol comprise about $50 \%$ of the cropfields of the South Transdanubian region in South Hungary. The highest yield in fresh as well as dry matter was achieved on Alfisol-Mollisol soil that contained moderate clay fraction and hence it bears a well balanced water and nutrient household. The Aquic Mollisol site was under the control of a relatively high ground water table, particularly in the spring, hindering the early development of the plantation. On the other hand, the high ground water table could serve as a good water source later in the summer, so the overall yield became high enough similarly to that on Alfisol-Mollisol. The relatively higher water content of the biomass produced on Aquic 
Mollisol, likely due to the better water availability, can be seen in Fig. 12. as a relatively high difference between the weight of the fresh and the dry matter. The lowest yield was measured on the Alfisol experimental site. Here, both the water and the nutrient supply was under the control of the high clay content of the soil which resulted in a relatively high dry matter content but an extremely low total biomass yield.

Temporal variability of biomass production of energy grass Szarvasi-1 was also studied in a three-year-long field experiment (2004-2007) in the South Transdanubian region (Hungary). According to our results, the main source of variability was the amount of precipitation. Particularly on the sites with low water table, biomass production decreased with up to $50 \%$ of the average biomass quantity in the year of extreme low precipitation. We measured 6 tons of dry matter per a hectare in 2007 instead of 12 tons of dry biomass yield in a better year (2006). Phenotypic plasticity of Szarvasi-1 energy grass cultivations can therefore be regarded as not very high, resulting in considerable variability of biomass yields in different years.

An extended fertilization experiment was conducted in two different environments in terms of climate and soil types in south-eastern and in south-western Hungary at a distance of 250 $\mathrm{km}$ from each other, in order to find the optimal nutrient supply of Szarvasi-1 energy grass crop (Fig. 13.). As our results suggested, the demand of energy grass for fertilization depends mainly on the soil types.

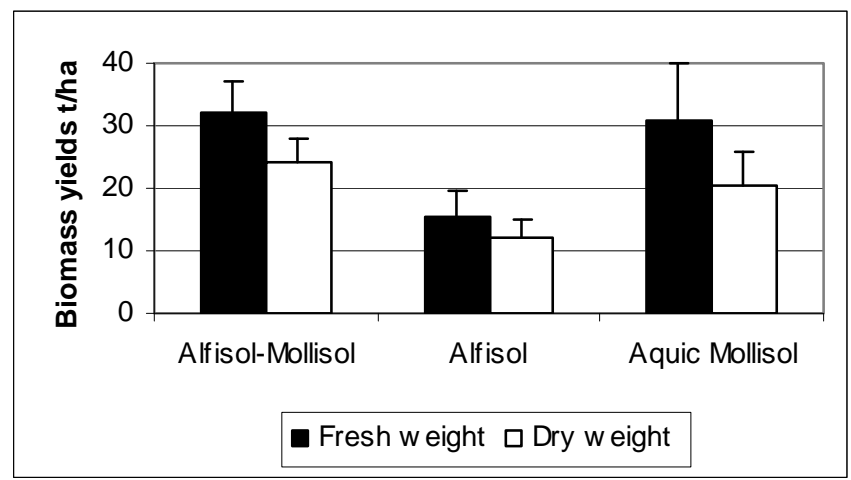

Fig. 12. Biomass yields in 2006 on three study sites near Bóly on different soil types (South Hungary) 


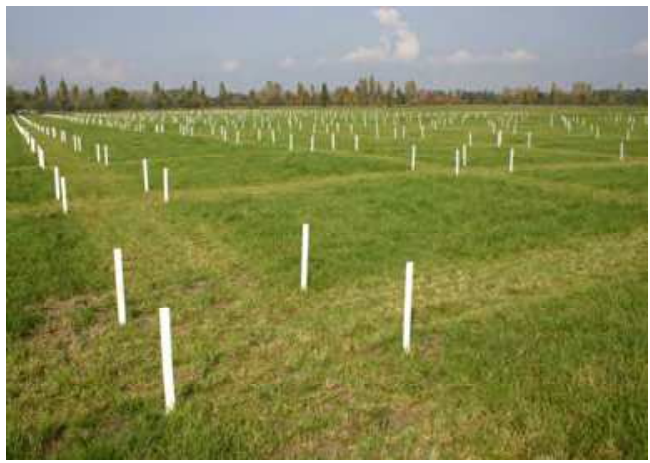

Fig. 13. Experimental fields near Szarvas (Southeast Hungary) to find optimal fertilizer management type (photo: Róbert W. Pál)

The response of biomass production to nitrogen is relatively high, already $60 \mathrm{~kg} \mathrm{~N} / \mathrm{ha}$ can double the dry biomass matter as can be seen in Fig. 14. Until this dose, increasing amounts of nitrogen contribute to increasing biomass production in a linear relationship. Higher doses than $60 \mathrm{~kg} /$ ha nitrogen by itself does not increase the biomass production further due to the lack of other major nutrients, such as potassium and phosphorus. Adding these to the experiment in different doses we have found that biomass production can be increased a further $50 \%$ until it reaches 13 tons dry matter per hectare. The best ratio of the three major nutrients was shown to be 1:1:1 or 3:2:2 to maximize biomass yield of energy grass.

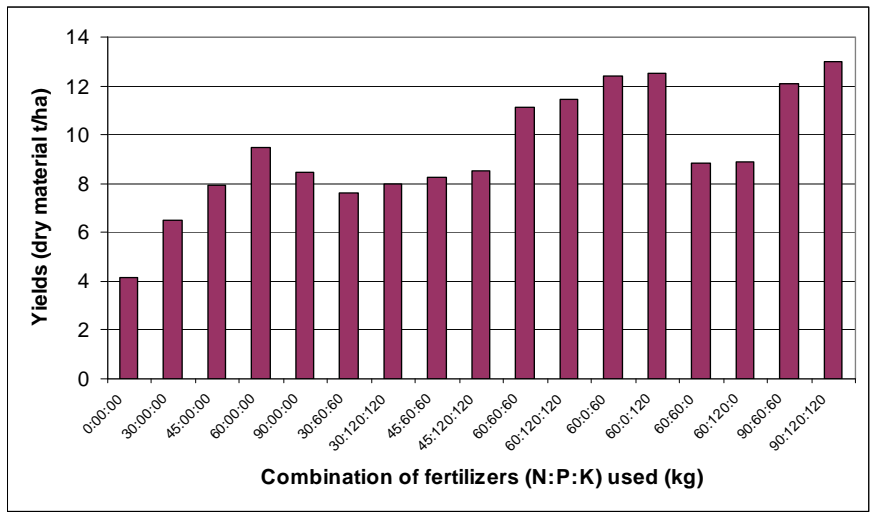

Fig. 14. Biomass yields from fertilizer study near Szarvas (solonec meadow soil)

Nitrogen played an important role in biomass production increasing biomass weight in any phenophases, while potassium and phosphorus were shown to be important only in the early phenophases (spring and flowering period and the beginning of the flowering time, respectively).

The maximum dry matter production of Szarvasi-1 energy grass crop was shown to be dependent on soil types and water supply. In our experiments 13 tons per hectare dry matter derived from solonec meadow soil, while in better soil conditions we got 20-25 tons dry matter per hectare. High and low levels of the average groundwater table can also decrease biomass 
yield substantially. Too high water table can prevent the energy grass crop forming closed and well established stands, while too low water table (less then $4 \mathrm{~m}$ in depth) can limit biomass production during the dry season in summer. As a consequence, the optimal water table level is estimated to be between 1 and 3 meters in depth in the course of the whole growing period.

In conclusion, we can claim that depending on the soil type, nutrient availability and precipitation, Szarvasi-1 energy grass crop can produce 10-25 dry matter/ha biomass a year, but this value cannot reach 5 tons in the case of soils with a high clay content and low precipitation. One harvest in the middle of August can achieve these biomass yields while in the rest of the year an additional $30-40 \mathrm{~cm}$ high second growth can be obtained. Beneficial choice of location for the establishment of Szarvasi-1 energy grass fields can result in considerably higher biomass yields increasing the competitive ability of this new biomass cultivation against conventional arable crops.

\section{Plant protection}

\subsection{Weeds}

\subsubsection{Weed composition of Szarvasi-1 fields}

Knowledge of weed assemblies is extremely important for an effective weed management in all arable cultures. Therefore introducing new crops to large scale cultivation requires comprehensive preliminary investigations. In this chapter the characteristic species composition as well as abundances of weeds on Szarvasi-1 energy grass fields were determined and were compared to other arable crop cultures. Weed-crop competition was also studied in different soil conditions. The analyses were made on the basis of 22 energy grass, 60 cereal, 60 row crop and 15 alfalfa plots that were $4 \times 4 \mathrm{~m}$ in size. A detailed study on this topic was published by Pál \& Csete (2008).

\subsubsection{Relation of weed species composition in energy grass to other arable cultures}

Comparing the weed composition of energy grass fields to other cultures on landscape and field level in terms of an ordination diagram showed a distinctive separation from cereals and row crops (Fig. 15.). A partial overlapping was detected with alfalfa fields, suggesting a similar species composition to this perennial crop.

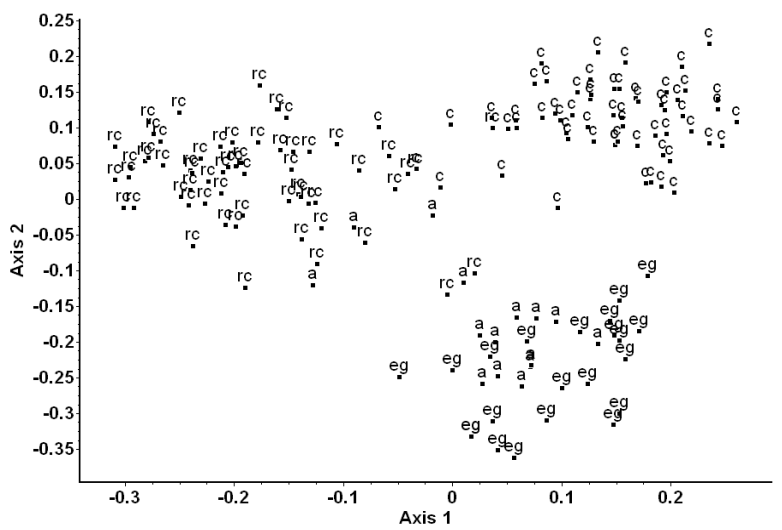

Fig. 15. Scatter diagram of the weed composition of different crops (eg = energy grass, $\mathrm{a}=$ alfalfa, $\mathrm{rc}=$ row crops, $\mathrm{c}=$ cereals $)(\mathrm{PCoA}$, Jaccard similarity index $)$ 
Regarding the life form distribution of the weeds in the different cultures, energy grass fields resembled annual crops the most, considering all life form categories. However, geophytes were more representative, while therophytes were less common. In alfalfa, a higher proportion of geophytes and hemicryptophytes were found, while therophytes were even more underrepresented than in energy grass fields. Considering the observed life form distribution of the characteristic weed community of each crop, energy grass took an intermediate position between annual crops and the perennial alfalfa.

The characteristic species composition of the different cultures is shown in Table 4 . There was only one species (Convolvulus arvensis) which could be regarded as uniformly common in every culture. There were 12 species characterizing the cereals, six the row crops, two in case of alfalfa and only one (Bromus japonicus) in case of energy grass. Bromus japonicus as a problematic weed was already present from the first year of sowing, and despite its annual life form, it has been continuously present and infesting the fields. On the other hand, energy grass fields are often characterized by a lack or a decreased importance of several serious weed species which are quite dominant in other arable crops: Amaranthus spp., Ambrosia artemisiifolia, Apera spica-venti, Artemisia vulgaris, Cirsium arvense, Echinochloa crusgalli, and Galium aparine.

\begin{tabular}{lcccc}
\hline Differential species & $\begin{array}{c}\text { Cereals } \\
\mathrm{n}=60\end{array}$ & $\begin{array}{c}\text { Row crops } \\
\mathrm{n}=60\end{array}$ & $\begin{array}{c}\text { Alfalfa } \\
\mathrm{n}=15\end{array}$ & $\begin{array}{c}\text { Energy } \\
\text { grass n=22 }\end{array}$ \\
\hline Cirsium arvense & 81.7 & 48.3 & 6.7 & 31.8 \\
Capsella bursa-pastoris & 73.3 & 10 & - & 22.7 \\
Papaver rhoeas & 73.3 & - & - & - \\
Artemisia vulgaris & 70 & 35 & 26.7 & 4.5 \\
Consolida regalis & 58.3 & 1.7 & - & 9.1 \\
Stellaria media & 58.3 & 10 & 6.7 & - \\
Veronica persica & 53.3 & 13.3 & 6.7 & - \\
Galium aparine & 48.3 & 3.3 & - & 4.5 \\
Apera spica-venti & 35 & - & - & - \\
Bromus sterilis & 30 & - & - & - \\
Viola arvensis & 30 & - & - & - \\
Veronica polita & 28.3 & - & - & - \\
Setaria pumila & 40 & 86.7 & 13.3 & - \\
Echinochloa crus-galli & 36.7 & 81.7 & 26.7 & - \\
Amaranthus chlorostachys & 1.7 & 50 & 13.3 & - \\
Digitaria sanguinalis & 1.7 & 46.7 & 13.3 & - \\
Persicaria maculosa & 10 & 45 & - & - \\
Solanum nigrum & 11.7 & 41.7 & 6.7 & - \\
Taraxacum officinale & 40 & 13.3 & 93.3 & 22.7 \\
Lolium perenne & 45 & 16.7 & 93.3 & - \\
Bromus japonicus & 10 & - & - & 81.8 \\
\hline Frequent species & & & & \\
\hline Convolvulus arvensis & 98.3 & 88.3 & 66.7 & 68.2 \\
Ambrosia artemisiifolia & 98.3 & 88.3 & 40 & 13.6 \\
Chenopodium album & 76.7 & 75 & 33.3 & 13.6 \\
\hline Table & & & & \\
\hline
\end{tabular}

Table 4. Frequencies of the weed species in different crops 


\subsubsection{Temporal variation of weed cover and species number}

Our results suggested that energy grass cultures are able to develop properly established, nearly weedless stands with an average crop cover that increased from 77.5 to $90 \%$ during a 4 year period. Furthermore, a quick leaf-litter accumulation was observed during this time reaching an average ground cover of leaf-litter of as much as $55 \%$. This can contribute to a significantly low weed cover. The average species number declined from 16.5 to 4.8 and the average ground cover decreased from 62.5 to $2 \%$. This dynamic process is depicted in an example from an experimental site from the South of Hungary on three different soil types (Fig. 16.).

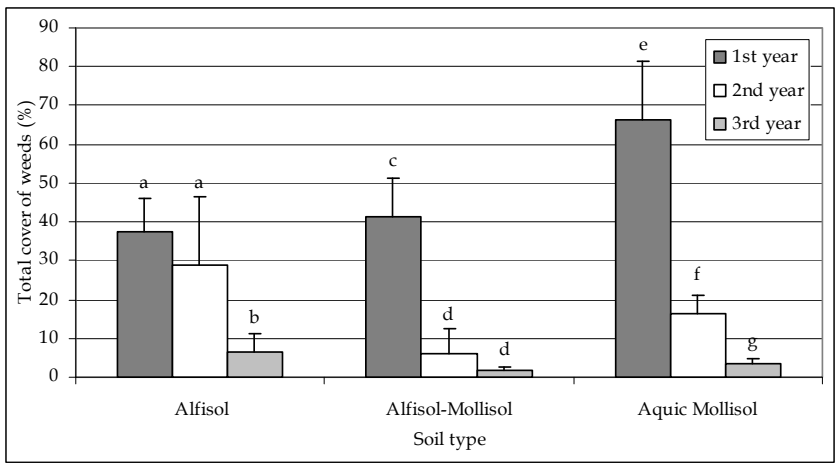

Fig. 16. Changes in total weed cover during three years on three different soil types.

Different letters indicate significant differences at $\mathrm{P}<0.05$; (mean, standard deviation); ( $\mathrm{t}-$ test)

\subsubsection{Competitive ability of energy grass on weeds}

The competitive ability of energy grass crop can be demonstrated using experimental plot data. A strong linear relationship was found between the biomass production and the logarithmic values of total weed cover suggesting a high competitive ability of the crop. With less then $10 \mathrm{t} /$ ha of biomass dry yield the cover of weeds exceeded $50 \%$, while at 15 $\mathrm{t} / \mathrm{ha}$ the value decreased to $20-25 \%$ and to $2-5 \%$ at $20 \mathrm{t} / \mathrm{ha}$.

Elymus elongatus is a rare, native plant species in Hungary; therefore its agricultural production is much more favourable than other exotic biomass grasses (e.g. Miscanthus $\times$ giganteus, Sorghum bicolor). Since its stands require a certain weed control only in the year of establishment, chemical input into the environment decreases significantly compared to other intensive cultures. Under favourable conditions, energy grass can entirely close its canopy and exclude more weed species or considerably decrease their cover by the third year of cultivation. This remarkable competitive ability of a crop is appreciated by farmers as it decreases the demand of herbicide use as well as the costs of the agricultural production.

\subsection{Fungi}

Studies on the pests of Szarvasi-1 energy grass are in progress in Hungary, but it is already clear that the plant is sensitive to many of the most common fungal infections typical for cereals. At our experimental sites the most important fungal infection was mildew (Blumeria 
graminis). Szarvasi-1 energy grass proved to be sensitive to mildew particularly on those sites where intensive growth of the plant occurred due to optimal nutrient and water availability. The mildew infection can cause severe damage on the leaf structure of the plant resulting in total devastation of whole patches. Proper chemical plant protection is needed to avoid significant biomass production loss. Infection of mildew was mediated by old hay bales deposited along the edge of energy grass fields, so the prompt collection and transportation of bales can contribute to lowering the chance of energy grass fields being reinfected. According to our results, chemical protection of energy grass fields must be taken into account similarly to that in the case of any other traditional agricultural crops.

\section{Ecological hazard}

Ecological invasion of neophyte plant and animal taxa has now become one of the most feared sources of natural habitat degradation according to many nationwide and international surveys (e.g. Molnár et al., 2008) The most frequent method of neophyte introduction is their agricultural use through which their large-scale distribution and successful establishment are intensively supported by human activities. Suggesting new plant taxa to be involved in agricultural production bears the hazard of suggesting a new potential invasive plant too. Hence thorough investigation and consideration must be taken before introducing any new agricultural crop, especially a new biomass plant.

Elymus elongatus is a rare, native plant species to Hungary; consequently its Szarvasi-1 cultivar is much more favourable for agricultural production in Hungary than other exotic biomass grasses. Szarvasi-1 carries genetic material that is derived from only indigenous populations of E. elongatus in Hungary. Hence the cultivar can be regarded as an indigenous taxon, so its potential as an ecological hazard in terms of invasivity is low. Since Szarvasi-1 energy grass has a transient seedbank type (i.e. its seeds lose their viability in a year), its cropfields can be transformed into any other crop without the problem of resprouting.

High competitive ability as well as fast growth dynamics are the main characters of Szarvasi-1 energy grass when it manages to establish itself completely. As our experiments suggested, weed species can outcompete Szarvasi-1 energy grass individuals if there is only incomplete sprouting and the development of tillers are slow. In this case, the stands of Szarvasi-1 energy grass crop remain open, and weeds can gain a significant advantage in growing and spreading. This is why we expect Szarvasi-1 energy grass not to be able to invade intact natural or semi-natural habitats, not even in the close vicinity of energy grass fields from where the seeds can escape in large quantities. Energy grass can germinate only in anthropogenic habitats where continuous and intensive disturbance takes place (e.g. field margins, dirt roads and banks following man-made canals). Since energy grass cannot spread vegetatively (i.e. with rhizomes), it will not become such a hazardous invasive species as for instance Solidago gigantea or Reynoutria japonica, at least not in its native habitat, in Eastern Europe.

For the rest of the world, it is worth being cautious. From Australia and the US the aggressive spread of energy grass has been reported (e.g. Cox, 2001; Walsh, 2008), where the plant formed homogeneous, closed stands outcompeting all the native elements of the local vegetation. Although this happened only in very close environments to the lands recultivated by Elymus elongatus (e.g. steep slopes and bank of canals), this might indicate the possibilities of its invasive spreading, particularly in those countries where natural specialist herbivores, as well as pathogenic agents of Elymus elongatus are missing. 


\section{Utilization}

The moisture content of the energy grass at harvest can highly influence the possibilities for storage, processing and utilization. Appropriate logistic and storage conditions can be provided by harvesting at the optimal time and the use of bales. In this manner the processing, chopping and direct energetic utilization of low moisture content of the baled fuel can be solved easily. High moisture content causes quality loss and negatively affects the processability and energetic characteristics of the material.

The application forms of energy grass used as fuel are:

- bale

- chips/chaff

- pellet

The physical and some of the energetic characteristics of the listed fuel forms are different. The characteristics are summarized in Table 5.

\begin{tabular}{|l|c|c|c|c|}
\hline \multicolumn{5}{|c|}{ Energy grass (abs. dry condition)* (Governing standards: MSZ EN 14961:2005) } \\
\hline & Unit & Bale & Chips/Chaff & Pellet \\
\hline Carbon & $\%$ & 46.594 & 44.938 & 45.815 \\
\hline Hydrogen & $\%$ & 3.487 & 4.322 & 3.733 \\
\hline Nitrogen & $\%$ & 0.988 & 1.151 & 1.26 \\
\hline Sulphur & $\%$ & 0.214 & 0.258 & 0.234 \\
\hline Oxygen & $\%$ & 44.156 & 44.636 & 42.551 \\
\hline Chlorine & $\%$ & 0.211 & 0.115 & 0.385 \\
\hline Ash & $\%$ & 4.35 & 4.58 & 6.02 \\
\hline Density & $\mathrm{kg} / \mathrm{dm}^{3}$ & $0.110-0.140$ & - & $1.114-1.225$ \\
\hline $\begin{array}{l}\text { Abrasion } \\
\text { index }\end{array}$ & $\%$ & - & - & 97.7 \\
\hline $\begin{array}{l}\text { Caloric } \\
\text { Value }\end{array}$ & $\mathrm{MJ} / \mathrm{kg}$ & 17.983 & 17.597 & 17.645 \\
\hline
\end{tabular}

* values were determined based on the average of several measurements

Table 5. The physical and some of the energetic characteristics of the listed fuel assortment

Data show that independently of its form the energy grass has high ash content. It is necessary to mention however that based on technological and laboratorial investigations we have found that the high ash content is mainly caused by external physical contaminants. This can be significantly reduced e.g. by training the operators in maintaining technological discipline and by using the appropriate harvest-, loading-, and storing processes of the raw material. The elemental compositions of the investigated fuels are also different from the ligneous fuels. Chlorine and sulphur content were investigated by $\mathrm{CHNS}$ analysis which shows several times higher values compared to premium quality fuels (according to standards). This factor must be considered for energetic utilization. Herbaceous fuels (such as the energy grass) have low ash melting point, which greatly restricts their energetic utilization. The results, which clearly show the change in amount of ash sample plotted against temperature for ligneous and herbaceous fuels, are summarized in Fig. 17. Based on the results of the measurements it can be stated that the ash melting point of the energy grass is $690^{\circ} \mathrm{C}$, while the ash melting point of the mixed wood-pellet is $1080^{\circ} \mathrm{C}$. 


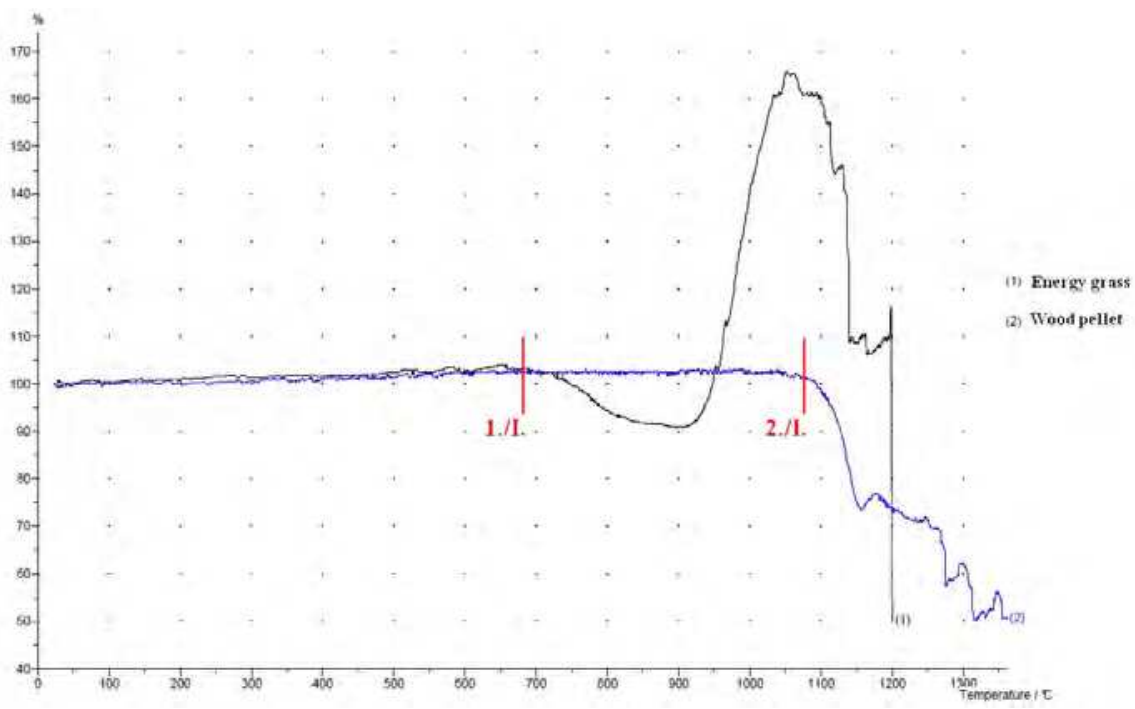

Fig. 17. Ash melting diagram of fuels

The high alkali content, which was adsorbed during the lifetime of the plant, causes the low ash melting point of the energy grass. This causes combustion problems because the ash melting occurs in the operating temperature of boiler. The material can melt and sick onto the surface of the structure elements of the boiler, and this will lead to interior depositions and permanent damage. To solve this problem, new boiler and grate types were developed. The part of the combustion chamber where the fuel burns in solid phase cannot reach high enough temperatures for the ash melting. Continuous movement of the fuel also helps to avoid scorification and interior depositions. Boiler technology was developed so that the fuel is moving on a moving grate in the boiler while the volatile component of the fuel is gasified between $150^{\circ} \mathrm{C}$ and $400^{\circ} \mathrm{C}$. The charred roughage falls off the grate to the ash pit before the fuel would be able to reach the critical melting temperature (Fig. 17.). The volatile component is burnt in the second part of the boiler (the so-called post-combustor) where the temperature of the combustion chamber is approx. $800-900^{\circ} \mathrm{C}$. The problem of ash melting was solved and sufficient burnout of the combustion gas was also ensured by this new technical solution. Based on this operating principle there are many structural solutions and performances available on the market.

The boilers, which are suitable for energetic utilization of the energy grass, can be ranked into three different groups based on their performance levels.

- $\quad$ low power equipment with pellet fuel $(\leq 50 \mathrm{~kW})$

- $\quad$ medium power equipment with pellet fuel $(50-300 \mathrm{~kW})$

- $\quad$ heat and power plant equipment with chips or bale fuel (0.3 - $5 \mathrm{MW})$

Due to their structure and size the low power equipments are mainly operated with pellet fuel. These automatic systems are suitable for the combustion of energy grass pellets with appropriate efficiency and low emission. The size of the boiler and the manufacturing cost are greatly increased by the necessary moving grate. These equipments are more robust than the prevalent wood-pellet boilers. Medium power equipments are primarily used in communal and social facilities, which are mainly operated using pellets. They are 
equipped with "travelling grates" which have a ladder-like structure and consist of more segments. There is another grate, so-called "crawler grate", which was named after its appearance because it resembles a looped ribbon stick. The heat and power plant boiler designs have several solutions. Utilization of the energy grass in coal power-plants was carried out with co-firing which can solve the problem of ash melting. During the combustion of herbaceous fuels higher solid emissions can be measured which mainly deposit in the boiler and exhaust with the flue gas. The efficiency is highly damaged by deposition on the heat transfer surfaces, and depending on the composition it can result in corrosive effects in the boiler. In order to prevent this, mechanical or pneumatic equipment should be installed with a dust separator, which cleans automatically the flue duct.

Parallel with this solution it is necessary to reduce the load of solid components of the flue gas, the equipment is usually mounted with cyclone, which allays larger floating particles from flue gas. Electrostatic filter may also be assessed, which significantly reduces the emission of solid component from boilers.

Another possible method for the energetic utilization of energy grass is the so-called pyrolytic procedure where the fuel is fumigated in a multistage process in an oxygen-low environment. The resultant "grass-gas" will be burnt directly or after a cleaning procedure it will be suitable for use in gas engines for electricity production. Because of the high capital costs these technologies are primarily economical in the case of using high-performance equipment. As a conclusion, it can be stated that problems concerning the use of the herbaceous fuels - including energy grass - in low-and high-performance boilers, directly, or with co-firing technique have been solved. The conditions of the application are determined by the logistic aspects and the current production costs. In the current boiler engineering, considering technical, energetic, environmental and economic aspects, the herbaceous fuels and their boilers may play an important role in the medium power-level market of energy systems.

\section{Conclusion}

A new energy crop (Elymus elongatus subsp. ponticus cv. Szarvasi-1, tall wheatgrass) has recently been introduced to cultivation in Hungary to provide biomass for solid biofuel energy production. The cultivar was developed in Hungary from a native population of $E$. elongatus subsp. ponticus for agronomic and energetic purposes. The main goal of our research was to investigate the performance of Szarvasi-1 energy grass under different growing conditions (e.g. soil types, nutrition supply). We focused on the ecological background, biomass yield, weed composition, morphology, ecophysiology and the genetics of the plant.

The biomass yield of Szarvasi-1 energy grass depends mainly on the presence of macronutrients, soil texture and water availability of fields. Under typical soil nutrient conditions, precipitation has a considerable effect on biomass yield. Average yield of Szarvasi-1 energy grass is as much as 10-15 t DM ha-1 with great spatial and temporal variation depending on weather and habitat conditions. As part of an intensive agricultural management, the use of fertilizers can be a good solution when soil nutrients are inadequate. Nitrogen plays an important role in increasing biomass in any phenophases of Szarvasi-1 in the course of annual growth (Fig. 18.). 


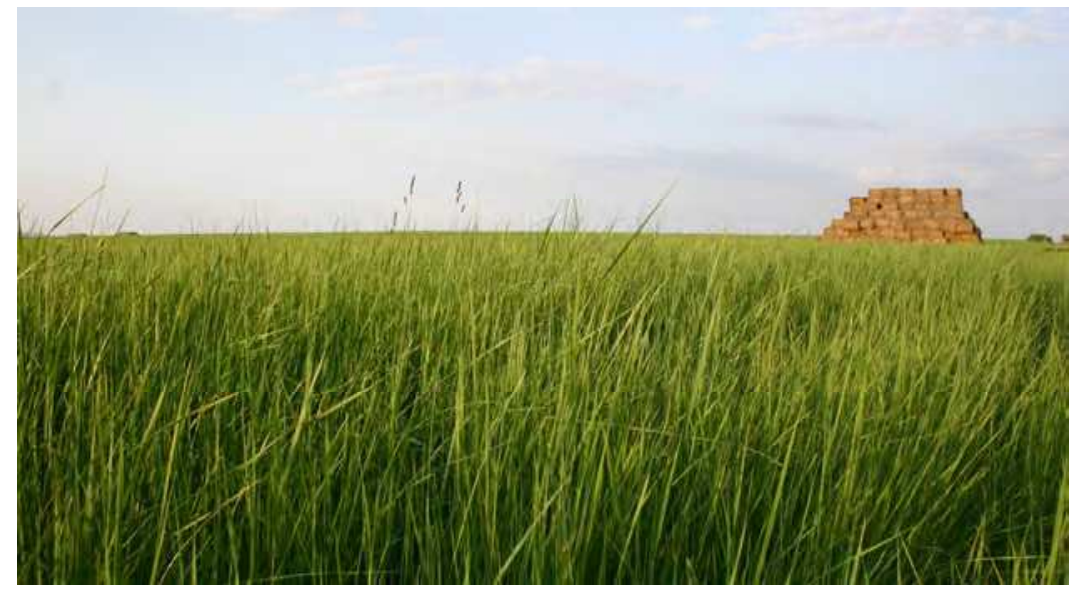

Fig. 18. Energy grass field in Baranya county (photo: Róbert W. Pál)

Quantitative analyses of the plant material of Szarvasi-1 were conducted to describe the chemical profile of the biofuel. Ash and energy content were determined by combustion experiments in laboratory while the dynamics of firing were studied in different experimental furnaces. We developed best practices for combusting Szarvasi-1 biofuel.

Dry matter content of Szarvasi-1 is highly influenced by the morphological features of the vegetative organs. The occurrence and proportion of mechanical and vascular tissues were investigated in the leaves and culms of Szarvasi- 1 in various experimental settings for two years. Having examined the effect of different soil types on the anatomical characteristics of the culm and the leaves, we determined the most favourable habitat types of this energy plant to achieve the highest biomass yields with the greatest dry matter content.

Ecophysiological regulation and the threshold limits of gas exchange parameters (assimilation, transpiration, water use efficiency, stomatal conductance) of Szarvasi-1 were also investigated. For abiotic environmental variables, air humidity and light had the most significant effect on gas exchange parameters. Assimilation curves and some characteristic values (e.g. light compensation and efficiency, assimilation capacity) were different at the beginning of the growing period on all studied soil types. These parameters characteristically declined under water-limited environmental conditions. Water limitation had a slightly positive effect on water use efficiency. Ecophysiological conclusions, drawn from gas exchange analyses, can be utilized for planning biological and agronomical aspects to achieve higher biomass production, in accordance with the abiotic environmental regime.

The typical weed composition and abundance in energy grass fields were compared to other arable crop cultures. Weed-crop competition was also investigated in different soil conditions. The weed composition of energy grass fields is more similar to perennial cultures like alfalfa than to other annual ones (cereals, row crops). Although no herbicide treatment was carried out, percent cover of Szarvasi-1 energy grass increased significantly year by year with decreasing weed cover and species number. By the second year, the average weed cover dropped from the first year's value of $48 \%$ to $17 \%$ and in the third year it did not exceed $4 \%$. Different soil types had different effect on the temporal variation of weed composition. 
In order to maintain a standard quality of Szarvasi-1 as an energy crop, it was essential to clarify its genetic characteristics. RAPD-based DNA fingerprinting revealed a low level of genetic variability among samples of the cultivar. In addition, a comparative analysis of three native Hungarian Elymus elongatus populations and Szarvasi-1 cultivar confirmed their genetic identity, having found no specific marker characteristic only for the latter. Ecological risk of unwanted gene exchange among close taxonomic relatives may be rather low but not impossible according to our results.

Moderate phenotypic plasticity, enormous capability to suppress weeds, high potential to produce biomass even among drier climatic conditions and a relatively high energy and moderate ash content suggest that tall wheatgrass cultivar Szarvasi-1 has great potential as a herbaceous energy plant for arid or semi-arid lands in Eastern Europe.

\section{Acknowledgement}

Our research and publication were financially supported by NKFP 3A/061/2004 and TÁMOP-4.2.2/B-10/1-2010-0029. Special thanks should be given to John Michael Lynch and Emily Rauschert for the thorough linguistic corrections of our manuscript.

\section{References}

Assadi, M. \& Runemark, H. (1995). Hybridization, genomic constitution and generic delimitation in Elymus sl (Poaceae, Triticeae). Plant Systematics and Evolution Vol. 194, No. 3-4, (September 1995), pp. 189-205, ISSN 0378-2697

Barkworth, M. (2011). Thinopyrum ponticum (Podp.) Z.W. Liu \& R.R.-C. Wang, In: Thinopyrum Á. Löve, 8 June 2011, Available from: $<$ http:// herbarium.usu.edu/webmanual/info2.asp?name=Thinopyrum_ponticum

Bleby, T.M.; Avcote, M.; Kennett-Smith, A.K.; Walker, G.P. \& Schachtman, R.P. (1997). Seasonal water use characteristics of tall wheatgrass (Agropyron elongatum (Host) Beauv.) in a saline environment. Plant Cell and Environment Vol. 20, No. 11, (November 1997), pp. 1361-1371, ISSN 0140-7791

Cox, G.W. (2001). An inventory and analysis of the alien plant flora of New Mexico. The New Mexico Botanist, Vol. 17, (January 2001), pp. 1-8.

Díaz, O.; Sun, G. L.; Salomon, B. \& Bothmer, R. (2000). Levels and distribution of allozyme and RAPD variation in populations of Elymus fibrosus (Poaceae). Genetic Resource and Crop Evololution, Vol. 47, No. 1, (February 2000), pp. 11-24, ISSN 0925-9864

Guadagnuolo, R.; Bianchi, D. S. \& Felber, F. (2001). Specific genetic markers for wheat, spelt, and four wild relatives: comparison of isozymes, RAPDs, and wheat microsatellites. Genome, Vol. 44, No. 4, (July 2001), pp. 610-621, ISSN 0831-2796

Häfliger, E. \& Scholz, H. (1980). Grass Weeds. Vol. 2. CIBA-GEIGY Ltd. Basel, Switzerland

Heslop-Harrison, Y. \& Shivanna, K.R. (1977). The Receptive Surface of the Angiosperm Stigma. Annals of Botany Vol. 41, (November 1977), pp. 1233-1258, ISSN 0305-7364

Janowszky, J. \& Janowszky, Zs. (2007). A Szarvasi-1 energiafú fajta - egy új növénye a mezőgazdaságnak és az iparnak (Szarvasi-1 energy grass - a novel crop for the agriculture and industry) In: Tasi, J. A magyar gyepgazdálkodás 50 éve Gödöllő, Szt. István Egyetem ISBN 978-963-9483-77-4 pp. 89-92

Johnson, R.C. (1991). Salinity resistance, water relations, and salt content of crested and tall wheatgrass accessions. Crop Science Vol. 31, (n.d.), pp. 730-734, ISSN 0011-183X 
Larcher, W. (2003). Physiological Plant Ecology. Ecophysiology and stress physiology of Functional Groups. Springer-Verlag, ISBN 3-540-43516-6, Berlin Heidelberg New York

Melderis, A. (1980). Elymus L., In: Flora Europaea, Vol. 5. Alismataceae to Orchidaceae (Monocotyledones), Tutin, T.G.; Heywood, V.H.; Burges, N.A.; Moore, D.M.; Valentine, D.H.; Walters, S.M. \& Webb, D.A., (Eds.), pp. 192-199, Cambridge University Press, ISBN-13: 9780521153706, Cambridge, England

Mizianty, M.; Frey, L. \& Szczepaniak, M. (1999). The Agropyron-Elymus complex (Poaceae) in Poland: nomenclatural problems. Fragmenta Floristica et Geobotanica Vol. 44, No. 1, (n.d.), pp. 3-33, ISSN 1640-629X

Molnár, Zs.; Bölöni, J. \& Horváth, F. (2008). Threatening factors encountered: Actual endangerment of the Hungarian (semi-) natural habitats. Acta Botanica Hungarica Vol. 50(Suppl.), (n.d.), pp. 199-217. ISSN 0236-6495

Murphy, M.A. \& Jones, C.E. (1999). Observations on the genus Elymus (Poaceae: Triticeae) in Australia. Australian Systematic Botany Vol. 12, No. 4 , (n.d.), pp. 593-604, ISSN 1030-1887

Nieto-López, R. M.; Casanova, C. \& Soler, C. (2000). Analysis of the genetic diversity of wild, Spanish populations of the species Elymus caninus (L.) Linnaeus and Elymus hispanicus (Boiss.) Talavera by PCR-based markers and endosperm proteins. Agronomie, Vol. 20, No. 8, (December 2000), pp. 893-905 ISSN 0249-5627

Pál R. \& Csete S. (2008). Comparative analysis of the weed composition of a new energy crop (Elymus elongatus subsp. ponticus [Podp.] Melderis cv. Szarvasi-1) in Hungary. Journal of Plant Diseases and Protection, Vol.21, (March 2008), pp. 215-220, ISSN 1861-4051

Petersen, G. \& Seberg, O. (1997). Phylogenetic Analysis of the Triticeae (Poaceae) Based on rpoA Sequence Data. Molecular Phylogenetics and Evolution, Vol. 7, No. 2, (April 1997), pp. 217-230, ISSN 1055-7903

Podani, J. (1993). SYN-TAX 5.0: Computer programs for multivariate data analysis in ecology and systematics. Abstracta Botanica, Vol. 17, Part 4 , (n.d.), pp. 289-302, ISSN 0133-6215

Reisch, C.; Poschlod, P. \& Wingender, R. (2003). Genetic differentiation among populations of Sesleria albicans Kit. ex Schultes (Poaceae) from ecologically different habitats in central Europe. Heredity, Vol. 91, No. 5, (November 2003), pp. 519-527, ISSN 0018-067X

Salamon-Albert É. \& Molnár H. (2009). CO2 gas exchange parameters as the measure of biomass production of the Hungarian energy grass. Proceedings of International Symposium on Nutrient Management and Nutrient Demand of Energy Plants July 6-8, 2009 Corvinus University Budapest, Hungary.

Salamon-Albert É. \& Molnár H. (2010). Environment regulated ecophysiological responses of a tall wheatgrass cultivar. Novenytermeles Vol. 59., No. 1., (n.d.), pp. 393-396, ISSN 2060-8543

Sha, 1., Fan, X., Yang, R., Kang, H., Ding, C., Zhang, L., Zheng, Y. \& Zhou, Y. (2010). Phylogenetic relationships between Hystrix and its closely related genera (Triticeae; Poaceae) based on nuclear Acc1, DMC1 and chloroplast trnL-F sequences. Molecular Phylogenetics and Evolution, Vol. 54, No. 2, (February 2010), pp. 327-335, ISSN 1055-7903

Swofford, D. L. (2001). PAUP*. Phylogenetic Analysis Using Parsimony (*and Other Methods) Version 4. Sinauer Associates, Sunderland, Massachusetts

Tutin, T.G.; Heywoog, V.H.; Burges, N.A.; Moore, D.M.; Valentine, D.H.; Walters, S.M. \& Webb, D.A. (1980). Flora Europaea Vol. 5 Alismataceae to Orchidaceae (Monocotyledones), Cambridge University Press, ISBN 978-052-1201-08-7, Cambridge, UK

Walsh, N.G. (2008). A new species of Poa (Poaceae) from the Victorian Basalt Plain. Muelleria, Vol. 6, No. 2, (July 2008), pp. 17-20, ISSN 0077-1813 


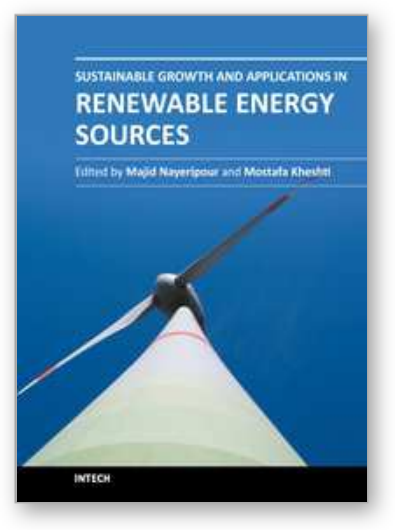

\section{Sustainable Growth and Applications in Renewable Energy Sources}

Edited by Dr. Majid Nayeripour

ISBN 978-953-307-408-5

Hard cover, 338 pages

Publisher InTech

Published online 02, December, 2011

Published in print edition December, 2011

Worldwide attention to environmental issues combined with the energy crisis force us to reduce greenhouse emissions and increase the usage of renewable energy sources as a solution to providing an efficient environment. This book addresses the current issues of sustainable growth and applications in renewable energy sources. The fifteen chapters of the book have been divided into two sections to organize the information accessible to readers. The book provides a variety of material, for instance on policies aiming at the promotion of sustainable development and implementation aspects of RES.

\section{How to reference}

In order to correctly reference this scholarly work, feel free to copy and paste the following:

Sándor Csete, Szilvia Stranczinger, Bálint Szalontai, Agnes Farkas, Róbert W. Pál, Eva Salamon-Albert, Marianna Kocsis, Péter Tóvári, Tibor Vojtela, József Dezső, llona Walcz, Zsolt Janowszky, János Janowszky and Attila Borhidi (2011). Tall Wheatgrass Cultivar Szarvasi-1 (Elymus elongatus subsp. ponticus cv. Szarvasi1) as a Potential Energy Crop for Semi-Arid Lands of Eastern Europe, Sustainable Growth and Applications in Renewable Energy Sources, Dr. Majid Nayeripour (Ed.), ISBN: 978-953-307-408-5, InTech, Available from: http://www.intechopen.com/books/sustainable-growth-and-applications-in-renewable-energy-sources/tallwheatgrass-cultivar-szarvasi-1-elymus-elongatus-subsp-ponticus-cv-szarvasi-1-as-a-potential-ene

\section{INTECH}

open science | open minds

\author{
InTech Europe \\ University Campus STeP Ri \\ Slavka Krautzeka 83/A \\ 51000 Rijeka, Croatia \\ Phone: +385 (51) 770447 \\ Fax: +385 (51) 686166 \\ www.intechopen.com
}

\author{
InTech China \\ Unit 405, Office Block, Hotel Equatorial Shanghai \\ No.65, Yan An Road (West), Shanghai, 200040, China \\ 中国上海市延安西路65号上海国际贵都大饭店办公楼 405 单元 \\ Phone: +86-21-62489820 \\ Fax: +86-21-62489821
}


(C) 2011 The Author(s). Licensee IntechOpen. This is an open access article distributed under the terms of the Creative Commons Attribution 3.0 License, which permits unrestricted use, distribution, and reproduction in any medium, provided the original work is properly cited. 